Rivers, J. W., K. N. Jones, and M. Betts. 2020. Neither forest herbicides nor ambient temperature exert strong effects on reproductive output of a cavity-nesting songbird. Avian Conservation and Ecology 15(1):18. https://doi.org/10.5751/ACE-01578-150118

Copyright (C) 2020 by the author(s). Published here under license by the Resilience Alliance.

Research Paper

\title{
Neither forest herbicides nor ambient temperature exert strong effects on reproductive output of a cavity-nesting songbird
}

\author{
James W. Rivers ${ }^{1}$, Kristin N. Jones ${ }^{2}$ and Matthew Betts ${ }^{3}$ \\ ${ }^{1}$ Department of Forest Engineering, Resources, \& Management, Oregon State University, Corvallis OR, ${ }^{2}$ U.S. Environmental \\ Protection Agency, Office of Pesticide Programs, Washington, D.C. $*{ }^{3}$ Forest Biodiversity Research Network, Department of Forest \\ Ecosystems \& Society, Oregon State University, Corvallis, OR
}

\begin{abstract}
Land management may combine with air temperature to influence the persistence of animal populations, so both must be evaluated in concert to understand how populations respond to increased forest management intensity and projected climate change. We used a large-scale study that experimentally manipulated herbicide application intensity within regenerating forests to test how herbicide-mediated changes in temperature influenced three components of reproductive output in the House Wren (Troglodytes aedon): nest survival, the number of offspring produced, and nestling body condition. We found no evidence for a consistent herbicide treatment effect on any reproductive measure, although our power to detect effects was modest. Relative to unsprayed controls, nest survival was lowest in the light herbicide treatment, and this measure increased on sites that were subjected to greater herbicide application (i.e., at moderate and intensive herbicide treatments), against our predictions. We also detected no evidence of a temperature effect singly or in combination with herbicide application on wren reproductive output. Although herbicide intensity was more influential on reproductive output than was temperature, we found that neither exerted strong effects in regenerating conifer forests. Given the dearth of studies that combine evaluations of temperature and land management impacts on songbird reproductive output, we suggest researchers continue to expand our understanding of the relative influence of both drivers simultaneously to better formulate conservation strategies in light of expected changes in climate and a heightened global demand for wood products.
\end{abstract}

\section{Ni les herbicides forestiers ni la température ambiante n'ont d'effets importants sur le succès reproducteur d'un passereau cavicole}

RÉSUMÉ. L'effet combiné des pratiques d'aménagement forestier et de la température de l'air pourrait influer sur la pérennité des populations animales, de sorte qu'on doit les évaluer de concert si on veut comprendre comment les populations réagissent aux pratiques forestières de plus en plus intenses et aux changements climatiques prévus. Nous avons utilisé une étude à grande échelle dans laquelle l'intensité de l'application d'herbicides dans les forêts en régénération a été manipulée afin de tester de quelle façon les changements de température induits par les herbicides influaient sur trois paramètres du succès reproducteur du Troglodyte familier (Troglodytes aedon) : la survie au nid, le nombre d'oisillons produits et la condition physique des oisillons. Nous n'avons pas constaté d'effet régulier d'un traitement aux herbicides sur les paramètres de reproduction examinés, bien que notre capacité à détecter les effets ait été modeste. Comparativement aux sites témoins sans arrosage, la survie au nid était le plus faible sous le traitement léger aux herbicides, et a augmenté aux sites sur lesquels davantage d'herbicides avaient été appliqués (c.-à-d. dans les traitements modéré et élevé aux herbicides), à l'encontre de nos attentes. De plus, nous n'avons pas détecté d'effet de la température, ni seule ni en combinaison avec l'application d'herbicides, sur le succès reproducteur du troglodyte. Même si l'intensité des herbicides a eu plus d'effet sur le succès reproducteur que la température, nous avons constaté qu'aucun d'eux n'a eu d'effets importants dans les forêts de conifères en régénération. Étant donné le manque d'études combinant l'évaluation des impacts de la température et des pratiques de gestion des terres sur le succès reproducteur des passereaux, nous incitions les chercheurs à continuer d'approfondir notre compréhension de l'effet relatif de ces deux facteurs simultanément afin de formuler de meilleures stratégies de conservation à la lumière des changements climatiques attendus et d'une demande mondiale accrue pour les produits du bois.

Key Words: forest herbicide; intensive forest management; microclimate; reproductive output; Troglodytes aedon; temperature

\section{INTRODUCTION}

In response to increased societal demand for wood products (FAO 2016), the application of intensive management practices within forests has become commonplace throughout the world (Carle and Holmgren 2008, Paquette and Messier 2010, Rodriguez et al. 2014). Such practices include shortened rotation length, planting of genetically improved trees, and the use of herbicides to control competing vegetation, among others (de Moraes Goncalves et al. 2014). Of these, the use of herbicides has the greatest potential to reduce the quality of regenerating forest because herbicides typically alter the composition and structure of early seral forest vegetation (Shepard et al. 2004, Balandier et al. 2006, Wagner et al. 2006), and their use can lead to a truncation of the early seral period (Swanson et al. 2014). In turn, a reduction in broadleaf

Address of Correspondent: James W. Rivers, Department of Forest Engineering, Resources, \& Management, Oregon State University, Corvallis OR 97331,jim.rivers@oregonstate.edu 
vegetation is thought to impact organisms that depend on early seral forest as critical habitat during the annual cycle (Willson and Comet 1996a, Hagar et al. 2007). For example, lepidopteran larvae are an important food source for songbirds during the breeding season (Rodenhouse and Holmes 1992) and are positively associated with broadleaf vegetation (Hammond and Miller 1998); thus, herbicide-mediated reductions in broadleaf cover are thought to reduce the extent and availability of this food source when songbirds rear their offspring. In addition, rates of nest failure can be higher under conditions of reduced deciduous vegetation available for nesting (Easton and Martin 1998, but see Rivers et al. 2019), so herbicide use in early seral forests has the potential to negatively impact songbird reproductive output indirectly through changes in both nesting and foraging habitat.

Increased air temperature is one of the most prominent components of ongoing human-driven climate change (IPCC 2013), and such increases have the potential to alter the demographic response of songbirds that nest in early seral forests where herbicide application is most prevalent. Subtle increases in temperature, for example, may enhance reproductive output by allowing incubating individuals to maintain greater levels of incubation constancy (Ardia et al. 2009), which, in turn, can lead to enhanced offspring body condition (Pérez et al. 2008) and may even enhance long-term survival (Andreasson et al. 2017). Warmer temperatures may also increase food availability for insectivorous birds whose foraging efficiency is reduced during cooler temperatures via higher thermoregulatory costs and reduced food availability (Avery and Krebs 1984, Winkler et al. 2002). In contrast, more pronounced temperature increases may have the opposite effect with negative consequences for organisms through alteration of metabolic rates (Schmidt-Nielsen 1997) and reductions in the survival of adults and their offspring (Selwood et al. 2015). For example, experimental increases in ambient temperature of temperate box-nesting populations of the Tree Swallow (Tachycineta bicolor) had strong consequences for the condition of females and their offspring, even when temperature increases were of short duration (Pérez et al. 2008, Ardia et al. 2009). Furthermore, heat stress can shift energy allocation to thermoregulation, reducing offspring growth (Murphy 1985, Pipoly et al. 2013, Salaberria et al. 2014), which may ultimately reduce postfledgling survival and influence population recruitment (du Plessis et al. 2012, Edwards et al. 2015). Thus, climate can influence temporal variation in vital rates for many species (McCarty 2001, Gallinat et al. 2015, Williams et al. 2015), even for those that have adapted to temperature regimes within temperate regions and select microhabitats to nest where temperature modulation is reduced, so this factor must be considered when evaluating the effects of management practices that alter vegetation composition.

Vegetation composition in forests can influence rates of surface cooling through changes in biophysical factors such as albedo and canopy conductance (von Arx et al. 2012, Zhao and Jackson 2014). Therefore, herbicide-mediated changes in vegetation composition may also lead to changes in ambient temperature, and these factors may work together to influence reproductive output (Sieving and Willson 1998, Chase et al. 2005). More broadly, expected changes in climate will combine with land use practices (Brook et al. 2008) to produce novel environmental conditions for many species (Hobbs et al. 2006, Mantyka-Pringle et al. 2012, Jantz et al. 2015, Northrup et al. 2019). Understanding how these pressures combine to affect vital rates is essential to conservation planning as both forest management and humandriven temperature change are expected to increase in extent and intensity in the coming decades (Lambin and Meyfroidt 2011, Seto et al. 2011, Tscharntke et al. 2012, IPCC 2013). Despite this, very few studies have examined the potential for combined effects of changes in vegetation and air temperature on animal vital rates within forest ecosystems (Cox et al. 2013, Becker and Weisberg 2015), and new studies are needed to fill these critical knowledge gaps.

In this study, we tested whether experimental herbicide application and ambient air temperature, both singly and in combination with each other, were linked to songbird reproductive output within intensively managed coniferous forests. Forest herbicides are designed to target plant-specific physiological mechanisms and are not known to directly influence animal populations when used at prescribed levels (Tatum 2004, McComb et al. 2008). It is worth noting that one widespread forest herbicide, glyphosate, has been shown to impact bird health under captive conditions, although investigations of direct effects on birds under field conditions are currently lacking (reviewed in Gill et al. 2018). For our investigation, we focused on evaluating the indirect effects of herbicides on songbird reproductive output in the cavity-nesting House Wren (Troglodytes aedon, hereafter wren) because this species is a long-distance migrant that typically arrives to our study area after spring herbicide application takes place and is therefore most likely to be affected by indirect consequences of forest herbicide application, e.g., changes in vegetation structure and composition. We selected the wren for study because it has experienced a strong, long-term decline in the Pacific Northwest, i.e., 3\% per year (Sauer et al. 2015), its abundance is known to initially decline with increases in herbicide application intensity (Betts et al. 2013), and it is strongly affected by climate across the western United States (Betts et al. 2019). Thus, decreases in the quality of early seral forest, changes in climate, or both may be linked to long-term wren population declines. We predicted that three components of wren reproductive output - nest survival, the number of offspring produced, and nestling body condition-would decrease with increasing management intensity as a result of herbicidemediated changes in vegetation. We also predicted that measures of reproductive output would be enhanced by increased maximum daily air temperatures throughout the breeding season up to a threshold (nestlings: $>30{ }^{\circ} \mathrm{C}$; eggs $>38-40.5^{\circ} \mathrm{C}$; Pipoly et al. 2013, Wada et al. 2015), beyond which reproductive output would decrease, i.e., a quadratic relationship. We focused our assessment on mean daily maximum temperature (hereafter $\mathrm{T}_{\max }$ ) for two reasons. First, maximum temperatures can be used to index other temperature values that are physiologically relevant to birds, i.e., minimum and mean temperatures, and we found all three of these measures were statistically indistinguishable among treatments in our study system (Jones et al. 2018). In addition, increasing surface temperatures from global warming are likely driving several trends in weather and climate, with the most important being warmer temperature patterns, e.g., frequency of heat waves, warmer days and nights, fewer cold days and nights (IPCC 2013). Additional increases in higher temperatures have the strongest potential to alter demographic responses of birds, 
particularly through changes in activity during the breeding season, e.g., foraging or nestling provisioning (du Plessis et al. 2012). As the first investigation to evaluate the combined effects of herbicide intensity and air temperature on songbird reproductive output, this study highlights the need for new investigations that help songbird conservation planning within early seral forests under expected increases in human-induced climate change and forest management intensity.

\section{METHODS}

\section{Study area and focal species}

We conducted this work within the western hemlock (Tsuga heterophylla) zone of the Oregon Coast Range (Franklin and Dyrness 1988), where mean annual temperature ranges from 8 to $9{ }^{\circ} \mathrm{C}$ and mean annual precipitation ranges from 165 to $330 \mathrm{~cm}$, with most precipitation occurring October through March (Franklin and Dyrness 1988, Taylor and Hannan 1999). Topography is characterized by somewhat low, highly dissected mountains with slopes ranging from 0 to $90 \%$ (Taylor and Hannan 1999). Intensively managed forest plantations in our region comprises largely Douglas-fir (Pseudotsugamenziesii), with grand fir (Abies grandis), western hemlock, and western red cedar (Thuja plicata) forming minor components. Dominant broadleaf vegetation species include big-leaf maple (Acer macrophyllum), California hazelnut (Corylus cornuta californica), cascara (Rhamnus purshiana), common snowberry (Symphoricarpos albus), oceanspray (Holodiscus discolor), red alder (Alnus rubra), and vine maple (Acer circinatum), with Oregon grape (Mahonia nervosa), salal (Gaultheria shallon), and Vaccinium spp. commonly occurring in the understory. The herbaceous community comprises many native and non-native herbaceous plants, with swordfern (Polystichum munitum) and brackenfern (Pteridium aquilinum) often dominating.

Our study species, the wren, is a small (10-12 g), insectivorous, long-distance migrant passerine that is found throughout much of North America (Johnson 2014). It is a cavity-nesting songbird that readily uses nest boxes (Johnson 2014) and is found in a wide variety of open wooded habitats in Oregon from mid-April to mid-August. Female wrens lay clutches of 4 to 8 eggs and can be double-brooded, with a high rate of hatching $(\sim 90 \%)$ and fledgling success ( 70-90\%; Johnson 2014). Females alone incubate the eggs and brood the nestlings; however, both adults feed the nestlings (Johnson 2014). Of note, whole broods within unshaded nest boxes can die of apparent hyperthermia even when temperatures are relatively mild $\left(\geq 32^{\circ} \mathrm{C}\right.$; Johnson 2014$)$.

\section{Experimental design and herbicide treatments}

Our study was undertaken as part of a broader investigation of biodiversity-timber production trade-offs that implemented a randomized complete block study design whereby 32 stands were located in eight separate blocks, with four treatment levels randomly applied to one stand within each block; for this study, we used a subset of 24 stands in six of the eight study blocks (Fig. 1). All blocks were located on intensively managed conifer forest across a $100 \mathrm{~km}(\mathrm{~N}-\mathrm{S})$ section of the northern Oregon Coast Range region, and all stands within each block were located $>5$ $\mathrm{km}$ from each other (Fig. 1) to ensure spatial independence of treatments and to reduce within-block variation in stand characteristics.

Fig. 1. Location of the eight study blocks used to examine the influence of intensive forest management on early-seral forest biodiversity in the Oregon Coast Range. The six study blocks used in this study to assess the influence of intensive forest management and air temperature on House Wren (Troglodytes aedon) reproductive output are indicated by black rectangles.

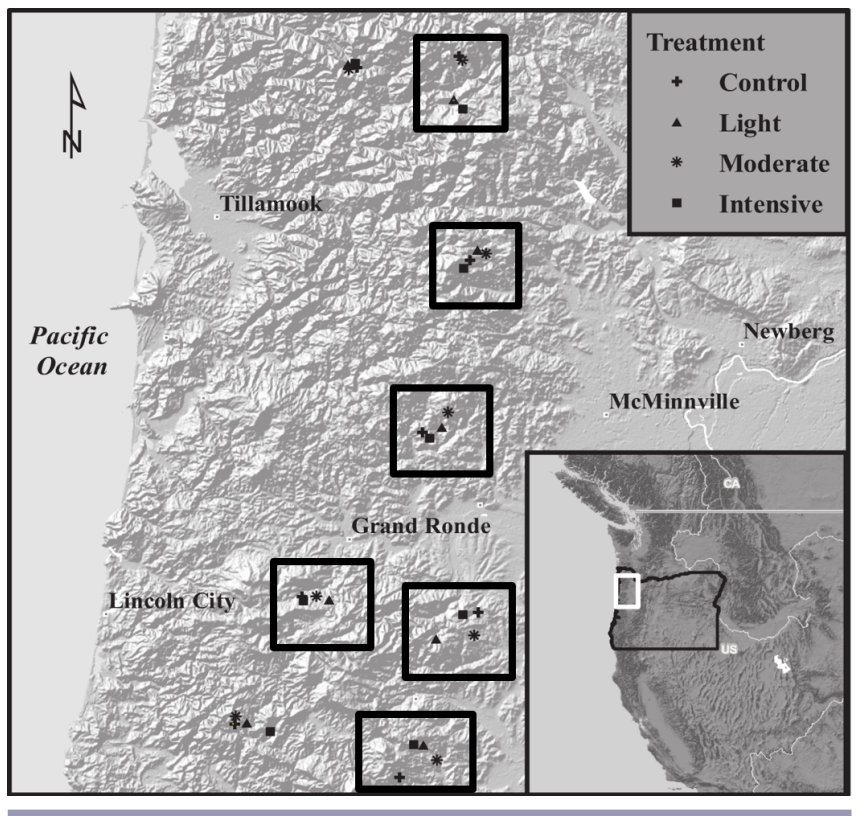

All study sites were clear-cut harvested in fall 2009/winter 2010 and replanted in spring 2011 with Douglas-fir, the most common commercial species in our region, at a density of 1100 trees per ha. A suite of herbicides and surfactants typically used in commercial timber management operations (described in Appendix 1) was applied to stands in a manner that created a gradient in management intensity (Betts et al. 2013, Jones et al. 2018). This gradient included light, moderate, and intensive herbicide treatments, in addition to no-spray controls that received no herbicide application at any time during the course of this study; this led to strong differentiation in the amount of broadleaf cover between treatments (Appendix 2). All herbicide applications occurred in the typical time frame in which vegetation control takes place in intensively managed timber operations, and included aerial application of chemicals by helicopter as well as ground-based backpack spraying. Of note, the light and moderate treatments represented the range of herbicide application from landowners in our study region, i.e., state lands and private industrial lands, respectively, and the intensive treatment was implemented to quantify the full range of biological responses to herbicide application.

We placed a total of eight nest boxes/stand $(n=192)$ that were constructed such that songbirds the size of a wren could access them for nesting, i.e., 3.8-cm diameter entrance hole. We sited nest boxes with several considerations in mind: (1) equal distances between boxes ( $>50 \mathrm{~m}$ separation), (2) even stand coverage, and (3) sampling logistics; vegetation was not a factor in box siting. 
We established nest boxes for secondary cavity-nesting species likely to colonize our study sites (e.g., Tachycineta swallows, Western Bluebird [Sialia mexicana], House Wren), but we found that wrens colonized the great majority of boxes across our study sites. Thus, decisions about box placement were made to provide spatial independence between boxes so that all could be used by a range of species, and were not made based on expected wren territory sizes.

We placed a single iButton temperature logger on the underside of each nest box to quantify ambient air temperature throughout the wren breeding season; the iButton data reported here were part of a related study looking at how intensive forest management influences ambient temperature (Jones et al. 2018). We placed each iButton so it hung freely $5 \mathrm{~cm}$ below the box and was covered with a section of white $10 \mathrm{~cm}$ diameter PVC tube containing ventilation holes to allow airflow, minimize heat accumulation, and prevent direct exposure of the iButton to solar radiation and moisture. We recorded air temperature outside of nest boxes because doing so allowed us to standardize measurements in a way that was impossible inside nest boxes on account of marked variation in the architecture of individual nests (see McCabe 1965). Our pilot data indicated that temperatures inside nest boxes were warmer than external temperatures throughout the breeding season $\left(\right.$ mean $=4.4{ }^{\circ} \mathrm{C}$ warmer, $\mathrm{SE}=0.8$; Jones, Rivers, and Betts, unpublished data), so our results provide a conservative measure of the temperatures experienced by eggs and nestlings within nest boxes. Because of logistical constraints, we used two iButton models that varied slightly in their accuracy $\left( \pm 1.0^{\circ} \mathrm{C}\right.$ accuracy, $\mathrm{n}=71$ boxes: $\pm 0.5^{\circ}$ C accuracy, $\mathrm{n}=89$ boxes), with the two models distributed evenly among stands. All iButtons were validated against an independent digital thermometer prior to placement (Omega HH609R, Omega Engineering, Norwalk, Connecticut, USA), and any iButton that deviated by $\geq 0.5^{\circ} \mathrm{C}$ during our testing procedure was not used.

We programmed each iButton to record temperature every $15 \mathrm{~min}$ throughout each 24-hour period, and we used these data to calculate the mean daily maximum temperature (hereafter $\mathrm{T}_{\max }$ ) during each observation interval starting at midnight and extending for $24 \mathrm{~h}$. Following previous studies using highresolution temperature data, we removed measurements that appeared to be erroneous or were caused by instrument malfunction or damage to logging stations by wildlife. Specifically, we considered temperature data to be erroneous when values were $>50{ }^{\circ} \mathrm{C}$ or $<-10{ }^{\circ} \mathrm{C}$ with no temporal or spatial precedence following Baker et al. (2014); this led us to remove $\sim 5 \%$ of temperature values.

\section{Measures of songbird reproductive output}

We monitored nest boxes every 3-4 days throughout the breeding season (late April to early August 2014) to determine the number of eggs and/or nestlings present on each visit and to quantify reproductive output. We considered a nest to be successful if it produced at least one offspring; we considered a nest to have failed if (1) parents were absent and $\geq$ one eggs were missing or broken, or (2) all nestlings were dead or missing prior to the expected earliest date of fledging (Martin and Geupel 1993); the few nests that had an uncertain fate were removed from analyses. We note that we detected only eight instances $(<3 \%)$ of a nest being abandoned out of the pool of $n=282$ nests that were located in this study, with two to three abandoned nests recorded in each treatment. Because nest abandonment was not biased toward any particular treatment(s) and occurred in a very small number of nesting attempts, excluding abandoned nests from analysis should not lead to any changes in our findings.

We quantified the number of nestlings that fledged from nests by taking the number of nestlings present on the last day we could visit nests without causing premature fledging, i.e., nestling day $8 / 9$, where day 0 is the hatch date, and subtracting any nestlings found dead in the nest after the nest had finished (hereafter the number of offspring produced). Thus, for this measure we explicitly restricted our focus to successful nests to quantify how many young fledged from the nest because temperature effects can have negative consequences for nestlings (Murphy 1985, Pipoly et al. 2013). Wren offspring do not reach their growth peak until nestling day 10-13 (Zach 1982), but we were unable to measure nestlings at later developmental stages because of the risk of premature fledging (Rivers and Jones, personal observation). In addition to the number of offspring produced, we also evaluated nestling body condition as a measure of offspring quality. During nest checks on nestling day $8 / 9$ we measured right tarsus length, right wing chord $( \pm 0.5 \mathrm{~mm})$, and body mass $( \pm 0.1 \mathrm{~g})$. Prior to analysis, we calculated the average body mass, tarsus length, and wing chord in each nest because nestlings sharing a nest are not independent in growth. Because of logistical constraints, we restricted our measurements of nestling body condition to four of the six study blocks (16 stands).

\section{Statistical analysis}

All models were fit in the $\mathrm{R}$ statistical environment (v3.2.0; $\mathrm{R}$ Core Team 2015), and we provide a summary of all a priori candidate models describing herbicide treatments and air temperature effects on wren nest survival, offspring production, and nestling body condition in Appendix 3. Models for the number of offspring produced and nestling body condition were fit using the lme function of the nlme package (Pinheiro et al. 2015). Nest survival models were fit using the glmer function of the lme4 package (Bates et al. 2015). We constructed three sets of linear mixed models, with each model representing a priori hypotheses about the three distinct measures of reproductive output, i.e., nest survival, the number of offspring produced, and nestling body condition, to separately model the relationship between (1) herbicide treatment and reproductive output, and (2) air temperature $\left(\mathrm{T}_{\max }\right)$ and reproductive output (using the same measures mentioned previously; see Table 1). We included models with and without a quadratic term for $T_{\max }$ because the relationship between reproductive measures and $T_{\max }$ could be nonlinear. For example, moderate increases in $\mathrm{T}_{\max }$ may benefit nestlings by reducing their thermoregulatory costs, but excessive increases in temperature could result in negative consequences via thermoregulatory behaviors, e.g., panting. We included elevation as a covariate in all models to control for differences in elevation between stands, and between nest box locations within stands. We also included three random effects in all models: (1) study block, (2) stand, and (3) nest box. The random effects for block and stand account for potential correlation of nest fates within blocks and stands, whereas the random effect for each nest box accounts for potential correlation of fates between nests occurring in the same 
Table 2. Parameter estimates of models testing for effects of herbicide treatment and $\mathrm{T}_{\max }$ on House Wren (Troglodytes aedon) nest survival, number of offspring produced, and nestling body condition. Model coefficients $(\beta)$ and $95 \%$ confidence intervals are given for each model. For nest survival models, odds ratios are also given. All model coefficients are model-averaged estimates.

\begin{tabular}{|c|c|c|c|c|c|}
\hline Model set / & Coefficient & $\beta$ & $95 \% \mathrm{CI}$ & Odds ratio & $95 \% \mathrm{CI}$ \\
\hline \multicolumn{6}{|c|}{ Nest survival } \\
\hline & Temperature & 0.12 & $-0.09,0.34$ & 1.13 & $0.91,1.40$ \\
\hline & Temperature*temperature & -0.14 & $-0.28,-0.01$ & 0.87 & $0.76,0.99$ \\
\hline & Light treatment & -1.35 & $-2.25,-0.45$ & 0.26 & $0.11,0.64$ \\
\hline & Moderate treatment & -0.87 & $-1.80,0.07$ & 0.42 & $0.17,1.07$ \\
\hline & Intensive treatment & -0.44 & $-1.48,0.59$ & 0.65 & $0.23,1.80$ \\
\hline \multicolumn{6}{|c|}{ Number of offspring produced } \\
\hline & Temperature & -0.01 & $-0.07,0.05$ & --- & --- \\
\hline & Temperature*temperature & 0.00 & $-0.01,0.01$ & --- & --- \\
\hline & Light treatment & -0.13 & $-0.56,0.30$ & --- & --- \\
\hline & Moderate treatment & -0.13 & $-0.55,0.29$ & --- & --- \\
\hline & Intensive treatment & 0.00 & $-0.45,0.44$ & --- & --- \\
\hline \multicolumn{6}{|c|}{ Nestling body condition } \\
\hline & Temperature & 0.00 & $-0.02,0.02$ & --- & --- \\
\hline & Temperature*temperature & 0.00 & $0.00,0.00$ & --- & --- \\
\hline & Light treatment & 0.02 & $-0.16,0.20$ & --- & --- \\
\hline & Moderate treatment & 0.01 & $-0.14,0.17$ & --- & --- \\
\hline & Intensive treatment & 0.02 & $-0.17,0.21$ & --- & --- \\
\hline
\end{tabular}

We found that although all models containing herbicide treatment were better supported than the null model $(\triangle \mathrm{AICc}=2.69$, evidence ratio $[E R]=3.83$; Table 1$)$, we did not detect an effect of herbicide treatment on daily nest survival (Fig. 2A, Table 2). Nevertheless, herbicide treatment did have a negative influence on mean daily survival rate when compared to the control treatment, with the greatest effect in the light treatment, with less pronounced effects in both the intensive and moderate treatments (Table 2, Fig. 2A). The parameter estimate confidence intervals for herbicide treatment effects on nest survival were large (Table 2), indicating modest statistical power to detect effects.

We also did not detect a relationship between $T_{\max }$ and nest survival (Fig. 2B, Table 2). Additionally, we did not find any evidence of a quadratic relationship between $\mathrm{T}_{\text {max }}$ and mean daily nest survival rate $(=-0.14,95 \% \mathrm{CI}:-0.28,-0.01$; Table 2$)$. We did find support for combined effects of treatment and $\mathrm{T}_{\text {max }}$ on mean daily survival rate, as the best supported model contained treatment, $\mathrm{T}_{\max }$ and its quadratic term $\left(w_{i}=0.35\right.$; Table 1$)$. However, the best supported model containing herbicide treatment and a quadratic effect of $\mathrm{T}_{\max }$ was only $1.3 \times$ more likely than the next best model, which contained treatment only $(\triangle \mathrm{AICc}$ $=0.53, \mathrm{ER}=1.30$; Table 1$)$. We note that the comparable $\triangle \mathrm{AICc}$ values of all models included in the model set $(\leq 4.08)$ in addition to comparable evidence ratios (Table 1) indicated that all hypotheses were equally plausible (Table 2 ).

On average, 4.9 ( $\pm 1.6 \mathrm{SD}$ ) offspring fledged from each successful nest across all treatments and the control. We did not detect an effect of treatment on the mean number of offspring fledged (Fig. $3 \mathrm{~A}$, Table 1), nor did we detect an effect of $\mathrm{T}_{\max }$ on the number of offspring produced per nest (Table 2). The best-supported model was the null model containing elevation and maximum brood size $\left(w_{i}=0.62\right.$; Table 1$)$. All models containing herbicide treatment had AICc weights $<0.04$ and evidence ratios $>16$ (Table 1). The mean number of offspring produced generally decreased with increasing $\mathrm{T}_{\max }$ (Fig. 3B); however, this estimated effect was very small (-0.01 nestlings $/ 1{ }^{\circ} \mathrm{C} ; 95 \% \mathrm{CI}$ : $\left.-0.07,0.05\right)$. We also did not detect evidence of a quadratic effect of $\mathrm{T}_{\max }$ on the number of offspring produced ( 0 nestlings $/ 1{ }^{\circ} \mathrm{C} ; 95 \% \mathrm{CI}$ : $\left.-0.01,0.01\right)$. However, comparable $\triangle \mathrm{AICc}$ values and evidence ratios for $\mathrm{T}_{\max }$ $(\triangle \mathrm{AICc}=2.01, \mathrm{ER}=2.73)$ and its quadratic term $(\triangle \mathrm{AICc}=3.81$, $E R=6.70)$ indicated that $T_{\text {max }}$ is an equally plausible explanation compared to the null model (Table 1). Finally, we did not find support for combined effects of treatment and $\mathrm{T}_{\max }$ on the mean number of offspring produced (Table 2); both models containing treatment and $\mathrm{T}_{\max }$ had $\Delta \mathrm{AICc}$ values $>7$ and ER $>47$ (Table 1).

On average, nestling mass on day $8 / 9$ averaged $8.86 \mathrm{~g}$ ( $\pm 0.76 \mathrm{SD})$ across all treatments and the control. The null model containing elevation, mean tarsus length, and mean nestling age was the bestsupported model $\left(w_{i}=0.36\right.$; Table 1$)$. However, the model containing treatment was the second best supported model $(\triangle \mathrm{AICc}=0.80, \mathrm{ER}=1.49)$, which suggests some support for an effect of treatment on mean nestling day $8 / 9$ body mass, with somewhat lower body mass in unsprayed controls (Fig. 4A). Similarly, we did not detect an effect of $\mathrm{T}_{\max }$ on nestling body condition (Table 2, Fig. 4B), nor did we detect evidence of a quadratic effect of $\mathrm{T}_{\text {max }}$ on mean nestling body condition (Table 2). Last, we did not find support for combined effects of treatment and $\mathrm{T}_{\max }$ on the mean number of offspring produced (Table 2). However, models containing treatment and $\mathrm{T}_{\max }$ and $\mathrm{T}_{\max }$ (quadratic) were $4.7 \times$ and $7.5 \times$ more likely than the null to explain variation in nestling body condition, respectively (Table 1 ). Thus, all hypotheses were equally plausible at explaining variation in nestling body condition, evidenced by comparable $\triangle$ AICc values and ERs of all models in the model set (Table 1). 
Fig. 2. Plots depicting the effect of herbicide treatment and $\mathrm{T}_{\max }$ and on House Wren (Troglodytes aedon) nest survival during the breeding season in the Oregon Coast Range, 2014.

(A) Differences in odds ratio estimates of nest survival between the effect of herbicide treatments relative to control stands; odds ratios were averaged over all models in the candidate set. The dashed horizontal line represents odds ratios of the control for comparison with herbicide treatments; $95 \%$ CIs that overlap one indicate lack of treatment differences relative to the control treatment. (B) Boxplots depicting $\mathrm{T}_{\max }$ values from nests that either failed (gray) or fledged offspring (white) across all four treatments. Horizontal bars within boxes represent medians, boxes are interquartile ranges, whiskers are $1.5 \times$ interquartile range, and dots are outlying data.
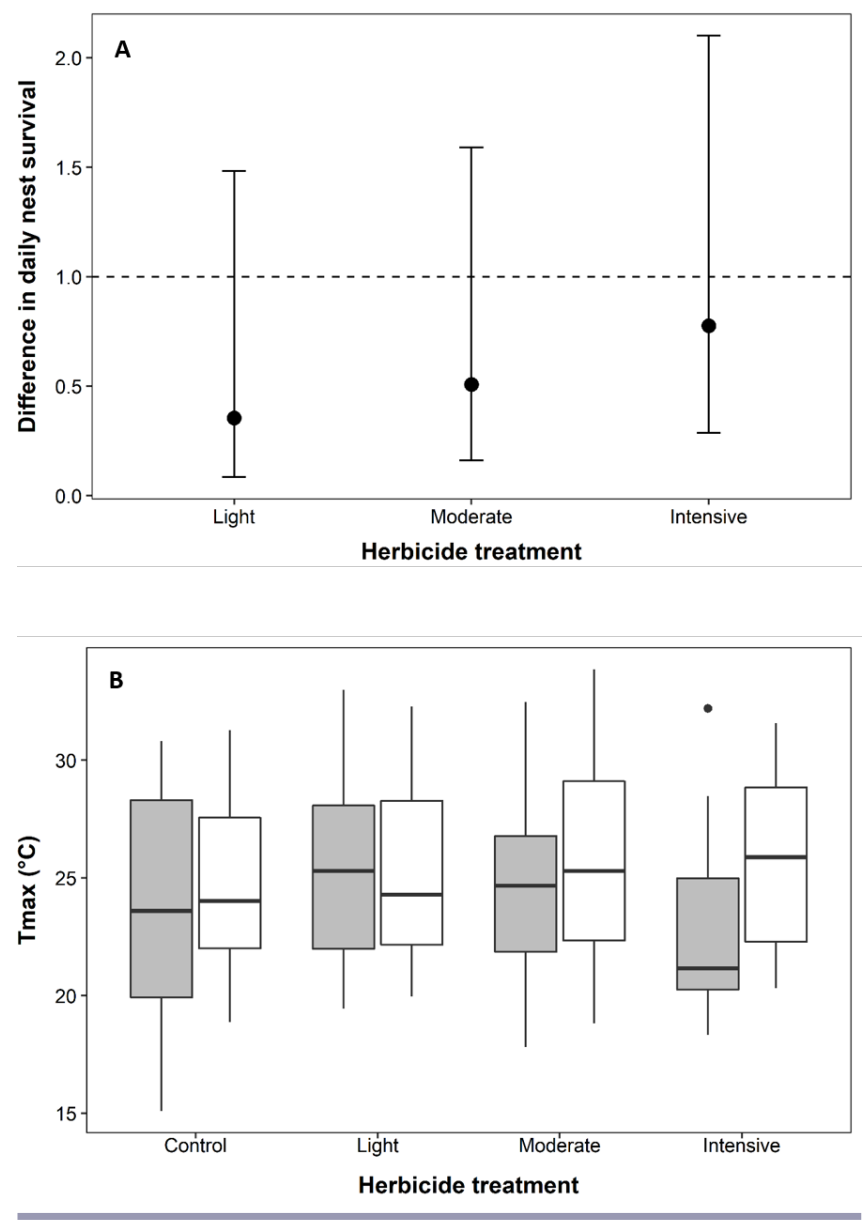

\section{DISCUSSION}

Our study found that the use of forest herbicides within intensively managed conifer stands did not have a strong influence on three measures of wren reproductive output: nest survival, the number of offspring produced, and nestling body condition. Furthermore it also found that air temperature effects on components of wren reproductive output were negligible, with little empirical support for a combined effect of herbicide treatment and air temperature. Of the factors we assessed, herbicide treatment appeared to have
Fig. 3. Number of offspring produced by House Wrens (Troglodytes aedon) summarized by (A) herbicide treatment and (B) $\mathrm{T}_{\max }$ during the breeding season in the Oregon Coast Range, 2014. (A) Boxplots depict the number of offspring produced by treatment. Bars are medians, circles are means, boxes are interquartile ranges, and whiskers are $1.5 \times$ interquartile range. (B) Relationship between $T_{\text {max }}$ and the number of fledglings produced per successful nest. The black line is a fitted linear regression line with $95 \%$ confidence intervals (gray shading).
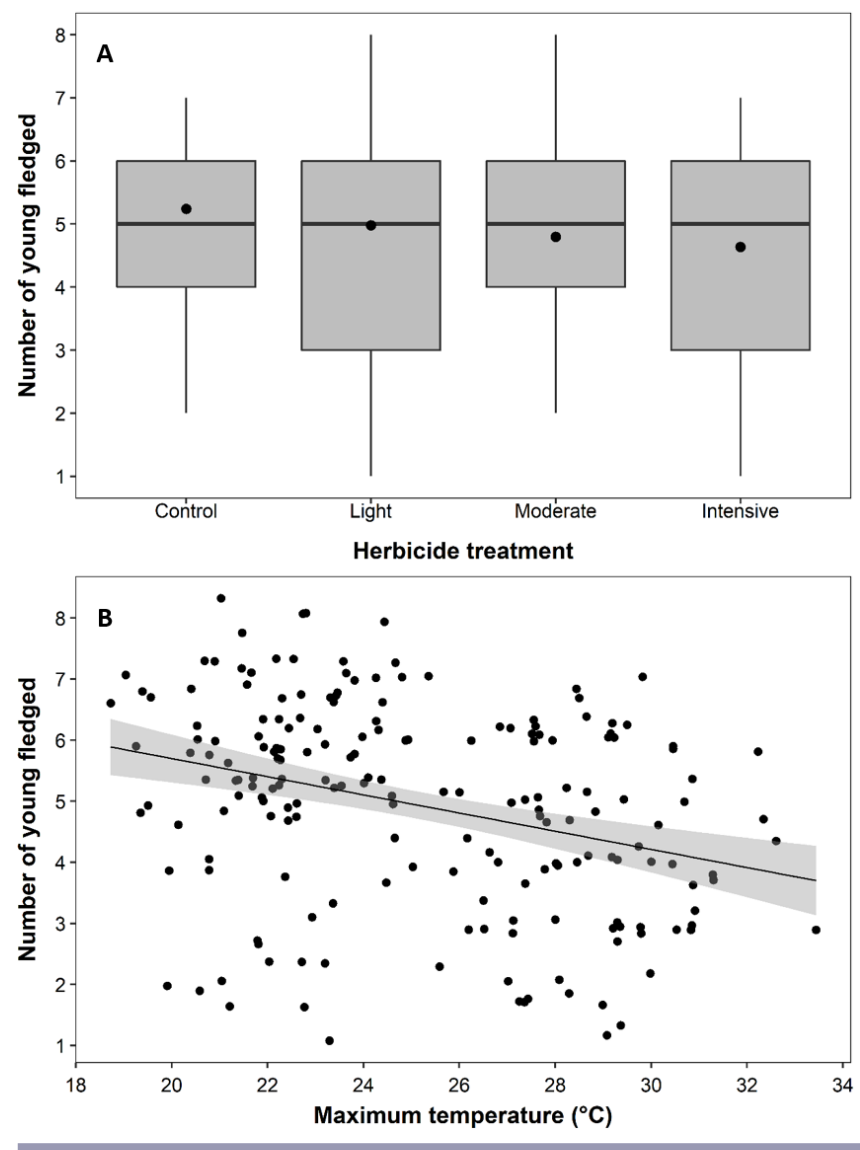

a stronger impact on wren nest survival than did temperature. That nest failure was driven almost entirely by predation suggests that the differences in nest survival between treatments we detected were caused by variation in the predator community, treatment-mediated differences in vegetation, or both. Among herbicide treatments, nest survival differed substantially; differences from control sites in the daily survival rate was $2.9 \times$ lower in the light treatment relative to the intensive treatment. Wren nest survival is known to decrease with increasing vegetation density at the nest (Belles-Isles and Picman 1986, Finch 1989, Li and Martin 1991, Hane et al. 2012), perhaps via enhanced hiding cover for small predators that can enter small nest cavities and are themselves subjected to higher-trophic predators, e.g., raptors. However, the notion that greater vegetation cover led to reduced nest survival was not supported in our study because predation rates were lowest in the control stands where vegetation cover was 
Fig. 4. House Wren (Troglodytes aedon) nestling body mass taken on day $8 / 9$ of the nestling period summarized by (A) herbicide treatment and (B) $\mathrm{T}_{\max }$ during the breeding season in the Oregon Coast Range, 2014. (A) Boxplots depict nestling body mass by treatment. Bars are medians, circles are means, boxes are interquartile ranges, and whiskers are $1.5 \times$ interquartile range. (B) Relationship between $\mathrm{T}_{\max }$ and nestling mass. The black line is a fitted linear regression line with $95 \%$ confidence intervals (gray shading).
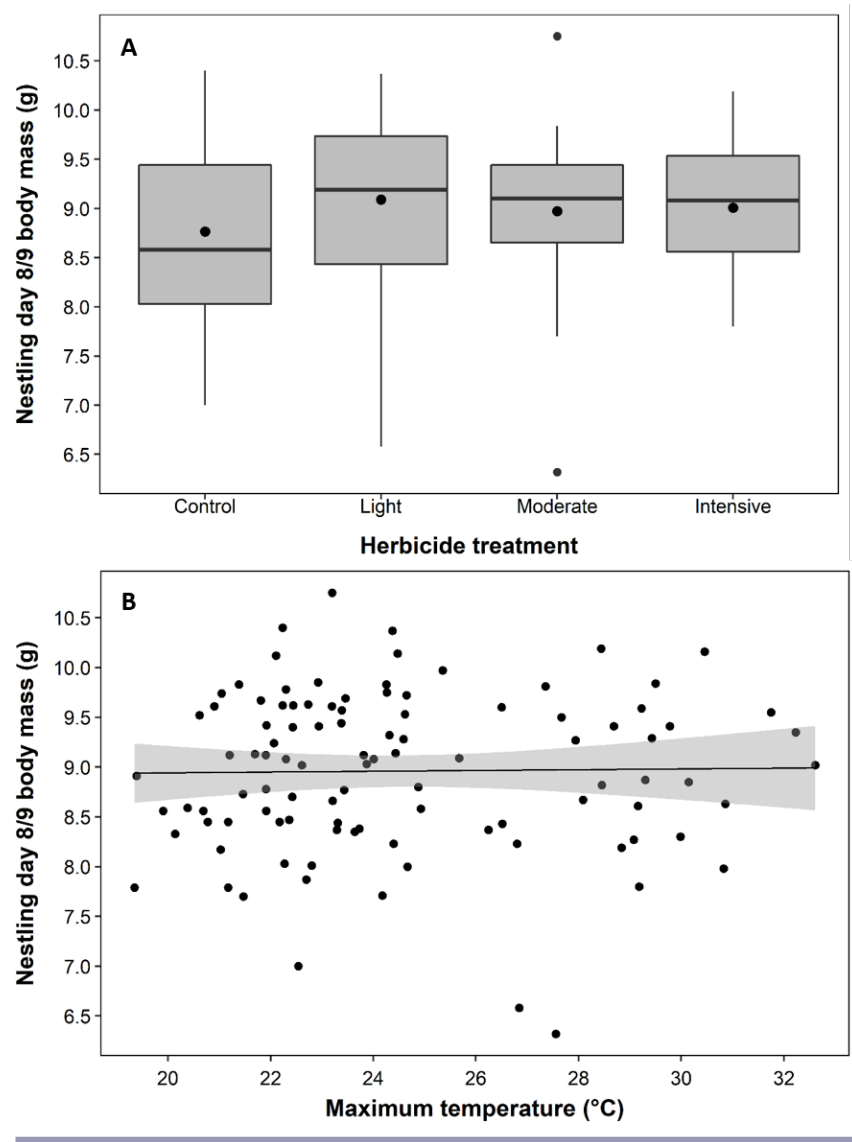

greatest and small predators would be expected to have the greatest amount of hiding cover. Another possibility is that conspecific egg-pecking behavior by wrens, a widespread behavior (Belles-Isles and Picman 1986, Johnson 2014), played a role in driving nest failure and varied across the herbicide treatments. Regardless of whether egg-pecking contributed to nest failure in our study, it is clear that the mortality agent(s) driving nest failure is not straightforward and leads us to conclude that changes in vegetation arising from forest herbicide application have an inconsistent relationship with wren nest survival.

The greater nest survival of wren nests in control sites relative to moderate and intensive herbicide treatments in our study is consistent with another study of the effects of herbicide-driven changes in vegetation composition on songbird nest survival (Easton and Martin 1998). However, the study by Easton and Martin focused on open-cup nesting songbirds and was conducted after a substantially longer period of time had passed following harvest relative to the time since harvest in our study (15-18 y vs. 3 y, respectively). Thus, additional factors influencing nest success are likely to have differed, making broad generalizations challenging. In contrast, results from this study differed from a recent study on reproductive output of the Whitecrowned Sparrow (Zonotrichia leucophrys). That study, which was conducted on some of the same stands as this investigation of wren reproductive output, found that sparrow nest survival was unrelated to herbicide intensity (Rivers et al. 2019). Although nest survival rates were lower in sparrows than in wrens (Rivers et al. 2019), the sparrow is an open-cup nesting species with a broader suite of predators than those capable of depredating nests of cavity-nesting species (Li and Martin 1991) and therefore would be expected to have nests that are more likely to fail due to predation. Given that only a handful of studies have evaluated how forest herbicides influence songbird vital rates and their conclusions have differed, there is no strong consensus at the current time about the role forest herbicides play in influencing songbird reproductive output, making additional investigations of this topic a priority.

In addition to influencing predation rates, a decrease in the cover of broadleaf vegetation may also influence songbird reproductive output by affecting the amount and quality of food available (Willson and Comet 1996b, Hagar 2007). For example, lepidopteran larvae, an important source of energy and nutrients for songbird nestlings (Rodenhouse and Holmes 1992), are positively associated with increased abundance of broadleaf vegetation (Hammond and Miller 1998, Miller et al. 2003). Thus, we expected that food availability would decrease with increasing herbicide treatment intensity, which would in turn result in decreased nestling body mass and/or the number of offspring produced. However, we found that herbicide treatment effects were as equally likely as our other hypotheses in explaining the number of offspring produced and their body mass, suggesting that herbicide application did not lead to differences in food availability for wrens. This idea is strengthened by data collected from our study stands that indicate stand-level arthropod biomass collected during the time of this study did not differ relative to herbicide treatment (Verschuyl, Rivers, and Betts, unpublished data), including a large-scale assessment of Lepidoptera (Root et al. 2017). This may be due to the generalist foraging approach used by wrens and the broad diet they feed to their nestlings (Johnson 2014; Rivers, unpublished data), which may result in wrens being less sensitive to changes in broadleaf vegetation as other early seral forest songbirds (Betts et al. 2010, Ellis and Betts 2011, Kroll et al. 2017). An alternative and nonmutually exclusive possibility for the lack of differences in the number of offspring produced or nestling body condition relates to compensatory behavioral responses of adults, assuming that realized food availability to wrens did indeed differ between treatments. Food limitation can strongly influence reproductive success and parents can adjust provisioning behaviors to a range of factors (e.g., Martin 1987, Peluc et al. 2008), so wren parents could have altered provisioning rates and/or food loads in a way that equalized offspring production even if food availability differed across treatments. We did not quantify adult provisioning in this study, so such behavioral adjustments by wren parents could help explain why we did not detect differences in reproductive output between treatments. Finally, we note that our assessment of body 
Avian Conservation and Ecology 15(1): 18

http://www.ace-eco.org/vol15/iss1/art18/

condition was necessarily limited to the period of chick development by our study design, and that the postfledging period is an especially challenging period in the songbird life cycle that is characterized by low survival rates (reviewed in Cox et al. 2014), including forest birds that use early seral conifer forests in our study area (Rivers et al. 2012, 2019). Studies of postfledging survival in songbirds, including wrens, are surprising limited (Cox et al. 2014), so it remains unknown if body condition in wren chicks could have had subsequent impacts on postfledging survival.

Our finding of a lack of combined effects of air temperature and herbicide-induced changes in vegetation differs from several previous studies that have found a relationship between air temperature and songbird reproduction (Cox et al. 2013, Becker and Weisberg 2015, Salaberria et al. 2014). One explanation for this disparity is that air temperatures in our study area may have been unlikely to exert negative effects on developing eggs and nestlings (Pipoly et al. 2013, Wada et al. 2015). For example, we found that $\mathrm{T}_{\max }$ never exceeded $33{ }^{\circ} \mathrm{C}$ at any of our study sites across the entire breeding season, which falls within the optimal range for eggs (DuRant et al. 2013), although it should be noted that temperatures $>30{ }^{\circ} \mathrm{C}$ have been shown to negatively affect nestling growth (Murphy 1985, Pipoly et al. 2013). Taken together, it would appear that temperature effects had limited influence on wren nestling growth because such high temperatures were relatively infrequent on our study sites, e.g., 18\% (340/1869) of all observation periods. Coupled with small effects of $\mathrm{T}_{\max }$ on nest survival and body condition and the relatively low variability surrounding these estimates, our results suggest that any combined effects of temperature, if they were present, had only a limited effect on wren reproductive output.

Habitat quality elements that may be altered by herbicide use in early seral forests include microclimatic air temperature, as well as vegetation composition and structure (Lehtinen et al. 2003). In our study, we found that patterns of within-season air temperature and herbicide-mediated changes in vegetation did not strongly affect songbird reproductive output in temperate, intensively managed, early seral coniferous forest, either singly or in concert with one another. Nevertheless, it is plausible that projected future increases in climate (IPCC 2013) may lead to combined effects of air temperature and forest cover change that reduce songbird reproductive output in ways that are not currently present. Herbicides are widely used in intensive forest management to control competing vegetation (Wagner et al. 2006), and their use in regenerating forests can alter the structure and function of early seral communities (Flueck and SmithFlueck 2006), especially in intensively managed conifer forests. Such areas are expected to meet increased demands for wood products in the coming decades (Sloan and Sayer 2015), so as climate change continues (IPCC 2013) researchers should recognize that both pressures must be considered in tandem to better understand the response of animal populations to global change. Furthermore, because land use change and climate can have a synergistic influence on animal populations (Northrup et al. 2019), additional studies that expand our understanding of the relative influence of each factor and their combined effect will be essential for formulating future conservation strategies.
Responses to this article can be read online at: http://www.ace-eco.org/issues/responses.php/1578

\begin{abstract}
Acknowledgments:
* This work is not a product of the United States Government or the U.S. Environmental Protection Agency. The author/editor is not doing this work in any governmental capacity. The views expressed are her/his own and do not necessarily represent those of the United States or U.S. EPA.

We thank C. Adlam, J. Bailey Guerrero, K. Zummo, B. Hardt, J. Powell, H. Beyl, S. Campbell, B. Cooney, G. Cummins, S. Doorly, E. Eve, D. Ferraro, C. Fitzmorris, N. Garlick, R. Hepner, S. Jordan, E. Keyes, C. Loucks, L. Mangan, T. Barron, N. Marcy, D. Millican, A. Muniz, L. Natola, E. Pokrivka, N. Volpe, K. Wilson, E. White, T. Barron, and T. Stokely for assistance in the field. We also thank A. Muldoon and L. Gaino for providing assistance with data analysis, and A. Kroll, J. Bakke, N. Palazzotto, and several anonymous reviewers for helpful comments on the original manuscript. Study site access and cooperation with implementing experimental treatments was granted by Weyerhaeuser, Hancock Timber Resource Group, the Oregon Department of Forestry and Plum Creek Timber. Funding was provided by grants from the USDA Agriculture Food and Research Initiative Program (AFRI-2009-04457, AFRI-2011-68005-30416), the National Council for Air and Stream Improvement, and the Fish and Wildlife Habitat in Managed Forests Research Program in the College of Forestry at Oregon State University.
\end{abstract}

\section{LITERATURE CITED}

Anderson, D. R. 2008. Model based inference in the life sciences: a primer on evidence. Springer Science and Business Media, New York, New York, USA.

Ardia, D. R., J. H. Pérez, E. K. Chad, M. A. Voss, and E. D. Clotfelter. 2009. Temperature and life history: experimental heating leads female Tree Swallows to modulate egg temperature and incubation behavior. Journal of Animal Ecology 78:4-13. https://doi.org/10.1111/j.1365-2656.2008.01453.x

Andreasson, F., A. Nord, and J.-A. Nilsson. 2017. Experimentally increased nest temperature affects body temperature, growth and apparent survival in Blue Tit nestlings. Journal of Avian Biology 49:jav-e01620 https://doi.org/10.1111/jav.01620

Avery, M. I., and J. R. Krebs. 1984. Temperature and foraging success of Great Tits Parus major hunting for spiders. Ibis 126:33-38. https://doi.org/10.1111/j.1474-919x.1984.tb03661.x

Baker, T. P., G. J. Jordan, E. A. Steel, N. M. Fountain-Jones, T. J. Wardlaw, and S. C. Baker. 2014. Microclimate through space and time: microclimatic variation at the edge of regeneration forests over daily, yearly and decadal time scales. Forest Ecology and Management 334:174-184. https://doi.org/10.1016/j.foreco.2014.09.008

Balandier, P., C. Collet, J. H. Miller, P. E. Reynolds, and S. M. Zedaker. 2006. Designing forest vegetation management strategies based on the mechanisms and dynamics of crop tree competition by neighbouring vegetation. Forestry 79:3-27. https://doi.org/10.1093/forestry/cpi056 
Barton, K. 2015. MuMIn: multi-model inference. $\mathrm{R}$ package version 1.14.0. [online] URL: http://CRAN.R-project.org/ package $=$ MuMIn

Bates, D., M. Mächler, B. Bolker, and S. Walker. 2015. Fitting linear mixed-effects models using lme4. Journal of Statistical Software 67:1-48. https://doi.org/10.18637/jss.v067.i01

Becker, M. E., and P. J. Weisberg. 2015. Synergistic effects of spring temperatures and land cover on nest survival of urban birds. Condor 117:18-30. https://doi.org/10.1650/condor-14-1.1

Belles-Isles, J.-C., and J. Picman. 1986. Nesting losses and nest site preferences in House Wrens. Condor 88:483-486. https://doi. org/10.2307/1368275

Betts, M. G., J. C. Hagar, J. W. Rivers, J. D. Alexander, K. McGarigal, and B. C. McComb. 2010. Thresholds in forest bird occurrence as a function of the amount of early-seral broadleaf forest at landscape scales. Ecological Applications 20:2116-2130. https://doi.org/10.1890/09-1305.1

Betts, M. G., J. G. Illán, Z. Yang, S. M. Shirley, and C. D. Thomas. 2019. Synergistic effects of climate and land-cover change on long-term term bird population trends of the western USA: a test of modeled predictions. Frontiers in Ecology and Evolution 7:186. https://doi.org/10.3389/fevo.2019.00186

Betts, M. G., J. Verschuyl, J. Giovanini, T. Stokely, and A. J. Kroll. 2013. Initial experimental effects of intensive forest management on avian abundance. Forest Ecology and Management 310:1036-1044. https://doi.org/10.1016/j.foreco.2013.06.022

Bowers, E. K., C. J. Hodges, A. M. Forsman, L. A. Vogel, B. S. Masters, B. G. Johnson, L. S. Johnson, C. F. Thompson, and S. K. Sakaluk. 2014. Neonatal body condition, immune responsiveness, and hematocrit predict longevity in a wild bird population. Ecology 95:3027-3034. https://doi.org/10.1890/14-0418.1

Brook, B. W., N. S. Sodhi, and C. J. A. Bradshaw. 2008. Synergies among extinction drivers under global change. Trends in Ecology and Evolution 23:453-460. https://doi.org/10.1016/j.tree.2008.03.011

Cade, B. S. 2015. Model averaging and muddled multimodel inference. Ecology 96:2370-2382. https://doi.org/10.1890/14-1639.1

Carle, J., and P. Holmgren. 2008. Wood from planted forests: a global outlook 2005-2030. Forest Products Journal 58:6-18.

Chase, M. K., N. Nur, G. R. Geupel, and P. Stouffer. 2005. Effects of weather and population density on reproductive success and population dynamics in a Song Sparrow (Melospiza melodia) population: a long-term study. Auk 122:571-592. https://doi. org/10.1093/auk/122.2.571

Cox, W. A., F. R. Thompson III, J. L. Reidy, and J. Faaborg. 2013. Temperature can interact with landscape factors to affect songbird productivity. Global Change Biology 19:1064-1074. https://doi.org/10.1111/gcb.12117

Cox, W. A., F. R. Thompson III, A. S. Cox, and J. Faaborg. 2014. Post-fledging survival in passerine birds and the value of postfledging studies to conservation. Journal of Wildlife Management 78:183-193. https://doi.org/10.1002/jwmg.670

de Moraes Goncalves, J. L., L. D. Silva, M. Behling, and C. A. Alvares. 2014. Management of industrial forest plantations. Pages 91-119 in J. G. Borges, L. Diaz-Balteiro, M. E. McDill, and L. C.
E. Rodriguez, editors. The management of industrial forest plantations: theoretical foundations and applications. Springer, Dordrecht, The Netherlands. https://doi.org/10.1007/978-94-017-8899-1_4

du Plessis, K. L., R. O. Martin, P. A. Hockey, S. J. Cunningham, and A. R. Ridley. 2012. The costs of keeping cool in a warming world: implications of high temperatures for foraging, thermoregulation and body condition of an arid-zone bird. Global Change Biology 18:3063-3070. https://doi.org/10.1111/ j.1365-2486.2012.02778.x

DuRant, S. E., W. A. Hopkins, G. R. Hepp, and J. R. Walters. 2013. Ecological, evolutionary, and conservation implications of incubation temperature-dependent phenotypes in birds. Biological Reviews 88:499-509. https://doi.org/10.1111/brv.12015

Easton, W. E., and K. Martin. 1998. The effect of vegetation management on breeding bird communities in British Columbia. Ecological Applications 8:1092-1103. https://doi.org/10.1890/1051-0761 (1998)008[1092:TEOVMO]2.0.CO;2

Edwards, E. K., N. J. Mitchell, and A. R. Ridley. 2015. The impact of high temperatures on foraging behaviour and body condition in the Western Australian Magpie Cracticus tibicen dorsalis. Ostrich 86:137-144. https://doi.org/10.2989/00306525.2015.1034219

Ellis, T. M., and M. G. Betts. 2011. Bird abundance and diversity across a hardwood gradient within early seral plantation forest. Forest Ecology and Management 261:1372-1381. https://doi. org/10.1016/j.foreco.2011.01.018

Finch, D. M. 1989. Relationships of surrounding riparian habitat to nest-box use and reproductive outcome in House Wrens. Condor 91:848-859. https://doi.org/10.2307/1368069

Flueck, W. T., and J. A. M. Smith-Flueck. 2006. Herbicides and forest biodiversity: an alternative perspective. Wildlife Society Bulletin 34:1472-1478. https://doi.org/10.2193/0091-7648(2006) 34[1472:HAFBAA]2.0.CO;2

Food and Agriculture Organization of the United Nations (FAO). 2016. State of the world's forests. FAO, Rome, Italy.

Franklin, J. F., and C. T. Dyrness. 1988. Natural vegetation of Oregon and Washington. General Technical Report PNW-8. U.S. Forest Service, Pacific Northwest Forest and Range Experiment Station, Portland, Oregon, USA.

Gallinat, A. S., R. B. Primack, and D. L. Wagner. 2015. Autumn, the neglected season in climate change research. Trends in Ecology and Evolution 30:169-176. https://doi.org/10.1016/j.tree.2015.01.004

Gelman, A., and Y. Su. 2015. arm: Data analysis using regression andmultilevel/hierarchicalmodels. R package version 1.8-5. http:// CRAN.R-project.org/package $=$ arm

Gill, J. P. K., N. Sethi, A. Mohan, S. Datta, and M. Girdhar. 2018. Glyphosate toxicity for animals. Environmental Chemistry Letters 16:401-426. https://doi.org/10.1007/s10311-017-0689-0

Grant, T. A., T. L. Shaffer, E. M. Madden, and P. J. Pietz. 2005. Time-specific variation in passerine nest survival: new insights into old questions. Auk 122:661-672. https://doi.org/10.1093/ auk/122.2.661

Greene, W. H. 2005. Censored data and truncated distributions. SSRN. https://doi.org/10.2139/ssrn.825845 
Hagar, J. C. 2007. Wildlife species associated with non-coniferous vegetation in Pacific Northwest conifer forests: a review. Forest Ecology and Management 246:108-122. https://doi.org/10.1016/j. foreco.2007.03.054

Hagar, J. C., K. M. Dugger, and E. E. Starkey. 2007. Arthropod prey of Wilson's Warblers in the understory of Douglas-fir forests. Wilson Journal of Ornithology 119:533-546. https://doi. org/10.1676/06-056.1

Hammond, P. C., and J. C. Miller. 1998. Comparison of the biodiversity of Lepidoptera within three forested ecosystems. Annals of the Entomological Society of America 91:323-328. https://doi.org/10.1093/aesa/91.3.323

Hane, M. E., A. J. Kroll, J. R. Johnson, M. Rochelle, and E. B. Arnett. 2012. Experimental effects of structural enrichment on avian nest survival. Forest Ecology and Management 282:167-174. https://doi.org/10.1016/j.foreco.2012.06.037

Hobbs, R. J., S. Arico, J. Aronson, J. S. Baron, P. Bridgewater, V. A. Cramer, P. R Epstein, J. J. Ewel, C. A. Klink, A. E. Lugo, et al. 2006. Novel ecosystems: theoretical and management aspects of the new ecological world order. Global Ecology and Biogeography 15:1-7. https://doi.org/10.1111/j.1466-822X.2006.00212. $\mathrm{x}$

Hosmer, D. W., and S. Lemeshow. 2013. Applied logistic regression. Third edition. Wiley \& Sons, Hoboken, New Jersey, USA.

Intergovernmental Panel on Climate Change (IPCC). 2013. Climate change 2013: the physical science basis. Contribution of Working Group I to the Fifth Assessment Report of the Intergovernmental Panel on Climate. T. F. Stocker, D. Qin, G.-K. Plattner, M. Tignor, S. K. Allen, J. Boschung, A. Nauels, Y. Xia, V. Bex, and P. M. Midgley, editors. Cambridge University Press, Cambridge, UK.

Jantz, S. M., B. Barker, T. M. Brooks, L. P. Chini, Q. Huang, R. M. Moore, J. Noel, and G. C. Hurtt. 2015. Future habitat loss and extinctions driven by land-use change in biodiversity hotspots under four scenarios of climate-change mitigation. Conservation Biology 29:1122-1131. https://doi.org/10.1111/cobi.12549

Johnson, L. S. 2014. House Wren (Troglodytes aedon). In A. Poole, editor. The birds of North America online. Cornell Lab of Ornithology, Ithaca, New York, USA. https://doi.org/10.2173/ bna. 380

Jones, K. N., J. W. Rivers, and M. G. Betts. 2018. Herbicides exert weak and variable effects on microclimate in early-seral forests. Northwest Science 92:107-118. https://doi.org/10.3955/046.092.0204

Kroll, A. J., J. Verschuyl, J. Giovanini, and M. G. Betts. 2017. Assembly dynamics of a forest bird community depend on disturbance intensity and foraging guild. Journal of Applied Ecology 54:784-793. https://doi.org/10.1111/1365-2664.12773

Labocha, M. K., and J. P. Hayes. 2012. Morphometric indices of body condition in birds: a review. Journal of Ornithology 153:1-22. https://doi.org/10.1007/s10336-011-0706-1

Lambin, E. F., and P. Meyfroidt. 2011. Global land use change, economic globalization, and the looming land scarcity. Proceedings of the National Academy of Sciences USA 108:3465-3472. https://doi.org/10.1073/pnas.1100480108
Lehtinen, R. M., J. B. Ramanamanjato, and J. G. Raveloarison. 2003. Edge effects and extinction proneness in a herpetofauna from Madagascar. Biodiversity and Conservation 12:1357-1370. https://doi.org/10.1023/A:1023673301850

Li, P., and T. E. Martin. 1991. Nest-site selection and nesting success of cavity-nesting birds in high elevation forest drainages. Auk 108:405-418.

Mantyka-Pringle, C. S., T. G. Martin, and J. R. Rhodes. 2012. Interactions between climate and habitat loss effects on biodiversity: a systematic review and meta-analysis. Global Change Biology 18:1239-1252. https://doi.org/10.1111/ j.1365-2486.2011.02593.x

Martin, T. E. 1987. Food as a limit on breeding birds: a life-history perspective. Annual Review of Ecology and Systematics 18:453-487. https://doi.org/10.1146/annurev.es.18.110187.002321

Martin, T. E., and G. R. Geupel. 1993. Nest-monitoring plots: methods for locating nests and monitoring success Journal of Field Ornithology 64:507-519.

McCabe, R. A. 1965. Nest construction by House Wrens. Condor 67:229-234. https://doi.org/10.2307/1365401

McCarty, J. P. 2001. Ecological consequences of recent climate change. Conservation Biology 15:320-331. https://doi.org/10.1046/ j.1523-1739.2001.015002320.x

McComb, B. C., L. Curtis, C. L. Chambers, M. Newton, and K. Bentson 2008. Acute toxic hazard evaluations of glyphosate herbicide on terrestrial vertebrates of the Oregon Coast Range. Environmental Science and Pollution Research International 15:266-272. https://doi.org/10.1065/espr2007.07.437

Miller, J. C., P. C. Hammond, and D. N. Ross. 2003. Distribution and functional roles of rare and uncommon moths (Lepidoptera: Noctuidae: Plusiinae) across a coniferous forest landscape. Annals of the Entomological Society of America 96:847-855. https://doi. org/10.1603/0013-8746(2003)096[0847:DAFROR]2.0.CO;2

Murphy, M. T. 1985. Nestling Eastern Kingbird growth: effects of initial size and ambient temperature. Ecology 66:162-170. https://doi.org/10.2307/1941316

Northrup, J. M., J. W. Rivers, Z. Yang, and M. G. Betts. 2019. Synergistic effects of climate and land-use change influence broad-scale avian population declines. Global Change Biology 25:1561-1575. https://doi.org/10.1111/gcb.14571

Paquette, A., and C. Messier. 2010. The role of plantations in managing the world's forests in the Anthropocene. Frontiers in Ecology and the Environment 8:27-34. https://doi.org/10.1890/080116

Paquette, S. R., F. Pelletier, D. Garant, and M. Belisle. 2014. Severe recent decrease of adult body mass in a declining insectivorous bird population. Proceedings of the Royal Society B: Biological Sciences 281:20140649. https://doi.org/10.1098/ rspb.2014.0649

Peluc, S. I., T. S. Sillett, J. T. Rotenberry, and C. K. Ghalambor. 2008. Adaptive phenotypic plasticity in an island songbird exposed to a novel predation risk. Behavioral Ecology 19:830-835. https://doi.org/10.1093/beheco/arn033

Pérez, J. H., D. R. Ardia, E. K. Chad, and E. D. Clotfelter. 2008. Experimental heating reveals nest temperature affects nestling 
condition in Tree Swallows (Tachycineta bicolor). Biology Letters 4:468-471. https://doi.org/10.1098/rsbl.2008.0266

Perrins, C. M. 1970. The timing of birds' breeding seasons. Ibis 112:242-255. https://doi.org/10.1111/j.1474-919X.1970.tb00096. $\mathrm{x}$

Pinheiro, J., D. Bates, S. DebRoy, D. Sarkar, and R Core Team. 2015. nlme: Linear and nonlinear mixed effects models. R package version 3.1-122.

Pipoly, I., V. Bókony, G. Seress, K. Szabó, and A. Liker. 2013. Effects of extreme weather on reproductive success in a temperatebreeding songbird. PLoS ONE 8:e80033. https://doi.org/10.1371/ journal.pone. 0080033

R Core Team. 2015. R: A language and environment for statistical computing. R Foundation for Statistical Computing, Vienna, Austria. URL http://www.R-project.org/

Rivers, J. W., A. L. Liebl, J. C. Owen, L. B. Martin, and M. G. Betts. 2012. Baseline corticosterone is positively related to juvenile survival in a migrant passerine bird. Functional Ecology 26:1127-1134. https://doi.org/10.1111/j.1365-2435.2012.02025.x

Rivers, J. W., J. Verschuyl, C. J. Schwarz, A. J. Kroll, and M. G. Betts. 2019. No evidence of a demographic response to experimental herbicide treatments by an early successional forest bird. Condor: Ornithological Applications 121:duz004. https://doi. org/10.1093/condor/duz004

Rodenhouse, N. L., and R. T. Holmes. 1992. Results of experimental and natural food reductions of breeding Blackthroated Blue Warblers. Ecology 73:357-372. https://doi. org/10.2307/1938747

Rodriguez, L. C. E., M. Pasalodos-Tato, L. Diaz-Balteiro, and J. P. McTague. 2014. The importance of industrial forest plantations. Pages 3-26 in J. G. Borges, L. Diaz-Balteiro, M. E. McDill, and L. C. E. Rodriguez, editors. The management of industrial forest plantations: theoretical foundations and applications. Springer, Dordrecht, The Netherlands. https://doi. org/10.1007/978-94-017-8899-1_1

Root, H. T., J. Verschuyl, T. Stokely, P. Hammond, M. A. Scherr, and M. G. Betts. 2017. Plant diversity enhances moth diversity in an intensive forest management experiment. Ecological Applications 27:134-142. https://doi.org/10.1002/eap.1426

Salaberria, C., P. Celis, I. Lopez-Rull, and D. Gil. 2014. Effects of temperature and nest heat exposure on nestling growth, dehydration and survival in a Mediterranean hole-nesting passerine. Ibis 156:265-275. https://doi.org/10.1111/ibi.12121

Sauer, J. R., J. E. Hines, J. E. Fallon, K. L. Pardieck, D. J. Ziolkowski, and W. A. Link. 2015. The North American Breeding Bird Survey, results and analysis 1966 - 2013. Version 01.30.2015. USGS Patuxent Wildlife Research Center, Laurel, Maryland, USA.

Schamber, J. L., D. Esler, and P. L. Flint. 2009. Evaluating the validity of using unverified indices of body condition. Journal of Avian Biology 40:49-56. https://doi.org/10.1111/j.1600-048X.2008.04462. $\mathrm{x}$
Schmidt-Nielsen, K. 1997. Animal physiology: adaptation and environment. Cambridge University Press, New York, New York, USA.

Selwood, K. E., M. A. McGeoch, and R. MacNally. 2015. The effects of climate change and land-use change on demographic rates and population viability. Biological Reviews 90:837-853. https://doi.org/10.1111/brv.12136

Seto, K. C., M. Fragkias, B. Güneralp, and M. K. Reilly. 2011. A meta-analysis of global urban land expansion. PLOS ONE 6: e23777. https://doi.org/10.1371/journal.pone.0023777

Shaffer, T. L. 2004. A unified approach to analyzing nest success. Auk 121:526-540. https://doi.org/10.1093/auk/121.2.526

Shaffer, T. L., and F. R. Thompson. 2007. Making meaningful estimates of nest survival with model-based methods. Studies in Avian Biology 34:84-95.

Shepard, J. P., J. Creighton, and H. Duzan. 2004. Forestry herbicides in the United States: an overview. Wildlife Society Bulletin 32:1020-1027. https://doi.org/10.2193/0091-7648(2004) 032[1020:FHITUS]2.0.CO;2

Sieving, K. E., and M. F. Willson. 1998. Nest predation and avian species diversity in northwestern forest understory. Ecology 79:2391-2402. https://doi.org/10.1890/0012-9658(1998)079[2391: NPAASD]2.0.CO;2

Sloan, S., and J. A. Sayer. 2015. Forest resources assessment of 2015 shows positive global trends but forest loss and degradation persist in poor tropical countries. Forest Ecology and Management 352:134-145. https://doi.org/10.1016/j.foreco.2015.06.013

Swanson, M. E., N. M. Studevant, J. L. Campbell, and D. C. Donato. 2014. Biological associates of early-seral pre-forest in the Pacific Northwest. Forest Ecology and Management 324:160-171. https://doi.org/10.1016/j.foreco.2014.03.046

Tatum, V. L. 2004. Toxicity, transport, and fate of herbicides. Wildlife Society Bulletin 32:1042-1048. https://doi.org/10.2193/0091-7648 (2004)032[1042:TTAFOF]2.0.CO;2

Taylor, G. H., and C. Hannan. 1999. The climate of Oregon: from rain forest to desert. Oregon State University Press, Corvallis, Oregon, USA.

Thompson, F. R. 2007. Factors affecting nest predation on forest songbirds in North America. Ibis 149:98-109. https://doi. org/10.1111/j.1474-919X.2007.00697.X

Tscharntke, T., Y. Clough, T. C. Wanger, L. Jackson, I. Motzke, I. Perfecto, J. Vandermeer, and A. Whitbread. 2012. Global food security, biodiversity conservation and the future of agricultural intensification. Biological Conservation 151:53-59. https://doi. org/10.1016/j.biocon.2012.01.068

von Arx, G., M. Dobbertin, and M. Rebetez. 2012. Spatiotemporal effects of forest canopy on understory microclimate in a long-term experiment in Switzerland. Agricultural and Forest Meteorology 166-167:144-155. https://doi.org/10.1016/j. agrformet.2012.07.018

Wada, H., B. Kriengwatana, N. Allen, K. L. Schmidt, K. K. Soma, and S. A. MacDougall-Shackleton. 2015. Transient and 
permanent effects of suboptimal incubation temperatures on growth, metabolic rate, immune function, and adrenocortical responses in zebra finches. Journal of Experimental Biology 218:2847-2855. https://doi.org/10.1242/jeb.114108

Wagner, R. G., K. M. Little, B. Richardson, and K. Mcnabb. 2006. The role of vegetation management for enhancing productivity of the world's forests. Forestry 79:57-79. https://doi.org/10.1093/ forestry/cpi057

Williams, C. M., H. A. Henry, and B. J. Sinclair. 2015. Cold truths: how winter drives responses of terrestrial organisms to climate change. Biological Reviews 90:214-235. https://doi.org/10.1111/ brv. 12105

Willson, M. F., and T. A. Comet. 1996a. Bird communities of northern forests: patterns of diversity and abundance. Condor 98:337-349. https://doi.org/10.2307/1369152

Willson, M. F., and T. A. Comet. 1996b. Bird communities of northern forests: ecological correlates of diversity and abundance in the understory. Condor 98:350-362. https://doi.org/10.2307/1369153

Winkler, D. W., P. O. Dunn, and C. E. McCulloch. 2002. Predicting the effects of climate change on avian life-history traits. Proceedings of the National Academy of Sciences USA 99:13595-13599. https://doi.org/10.1073/pnas.212251999

Zach, R. 1982. Nestling House Wrens: weight and feather growth. Canadian Journal of Zoology 60:1417-1425. https://doi. org/10.1139/z82-191

Zhao, K., and R. B. Jackson. 2014. Biophysical forcings of landuse changes from potential forestry activities in North America. Ecological Monographs 84:329-353. https://doi.org/10.1890/12-1705.1 
Appendix 1. Description of treatments used to evaluate the influence of forest herbicides on the reproductive output of House Wrens.

Trees were planted at a density of 1100 trees/ha in early spring 2011 on all stands. Prior to planting (2010), stands in the moderate and intensive herbicide treatments received site preparation treatment (i.e. broadleaf vegetation spray) that consisted of $0.10 \mathrm{~kg}$ ha- 1 Escort (DuPont, Wilmington, Delaware; active ingredient (a.i.) 60 percent metsulfuron methyl), $7.01 \mathrm{~L}$ ha-1 Accord (Dow AgroSciences LLC, Indianapolis, Indiana; a.i. 41.5 percent glyphosate), 1.75 L ha-1 Chopper (BASF Corporation, Florham Park, New Jersey; a.i. 27.6 percent imazapyr), $0.21 \mathrm{~kg}$ ha-1 Oust (DuPont, Wilmington, DE; a.i. 75 percent sulfometuron methyl), and 1.75 L ha-1 MSO (methylated seed oil, as surfactant) applied aerially via helicopter. Following planting, a spring herbaceous release spray was applied to stands in the light, moderate and intensive herbicide treatments which consisted of $2.98 \mathrm{~kg}$ ha-1 Velpar (DuPont, Wilmington, DE; a.i. 75 percent hexazinone), and $2.24 \mathrm{~kg}$ ha-1 2,4-D (Dow AgroSciences LLC, Indianapolis, IN; a.i. 97.5 percent 2,4-dichlorophenoxy acetic acid) applied aerially via helicopter or with groundbased backpack sprayers. Control stands did not undergo site preparation nor were they treated with herbicides (i.e. either spring herbaceous spray or broadleaf release) at any time during the course of this study.

In the second and third year after planting (2012 and 2013), stands in the intensive herbicide treatment received a spring herbaceous release spray that consisted of $0.14 \mathrm{~kg} \mathrm{ha}-1$ Oust XP (DuPont, Wilmington, DE; a.i. 75 percent sulfometuron methyl), $0.42 \mathrm{~kg}$ ha-1 Transline (Dow AgroSciences LLC, Indianapolis, IN; a.i. 40.9 percent clopyralid), and $1.49 \mathrm{~kg}$ ha-1 Velpar 
(DuPont, Wilmington, DE; a.i. 75 percent hexazinone) applied aerially via helicopter or with ground-based backpack sprayers. Finally, a broadleaf release spray was applied to stands in the light (2012 only) and intensive herbicide treatments (2012, and as needed in 2014) that consisted of 2.63 L ha-1 Accord (Dow AgroSciences LLC, Indianapolis, Indiana; a.i. 41.5 percent glyphosate) and 1.46 L ha-1 Garlon 4 (7.01 L ha-1 Accord (Dow AgroSciences LLC, Indianapolis, Indiana; a.i. 60.5 percent triclopyr) applied aerially via helicopter or with groundbased backpack sprayers. 
Appendix 2. Means ( $\pm 1 \mathrm{SD}$ ) for stand-level vegetation attributes for sites subjected to control, light herbicide, moderate herbicide, and intensive herbicide application in the Oregon Coast Range, 2014. Vegetation cover was measured June-August 2014 during the height of the growing season, and was averaged over three sample points taken at each nest box first before being averaged over all nest boxes on a stand.

\begin{tabular}{cccc}
\hline Treatment & Broadleaf cover & Conifer cover & Canopy cover \\
\hline Control & $59.4 \%(32.6 \%)$ & $5.6 \%(4.5 \%)$ & $3.6 \%(6.4 \%)$ \\
Light & $59.0 \%(32.4 \%)$ & $7.8 \%(6.7 \%)$ & $4.2 \%(7.6 \%)$ \\
Moderate & $13.5 \%(16.4 \%)$ & $10.2 \%(5.1 \%)$ & $0.4 \%(0.8 \%)$ \\
Intensive & $9.0 \%(7.1 \%)$ & $15.0 \%(9.4 \%)$ & $0.9 \%(2.2 \%)$ \\
\hline
\end{tabular}


Appendix 3. A priori candidate models describing herbicide treatment and air temperature effects on House Wren nest survival, number of offspring produced, and nestling body condition in the Oregon Coast Range, US, 2014

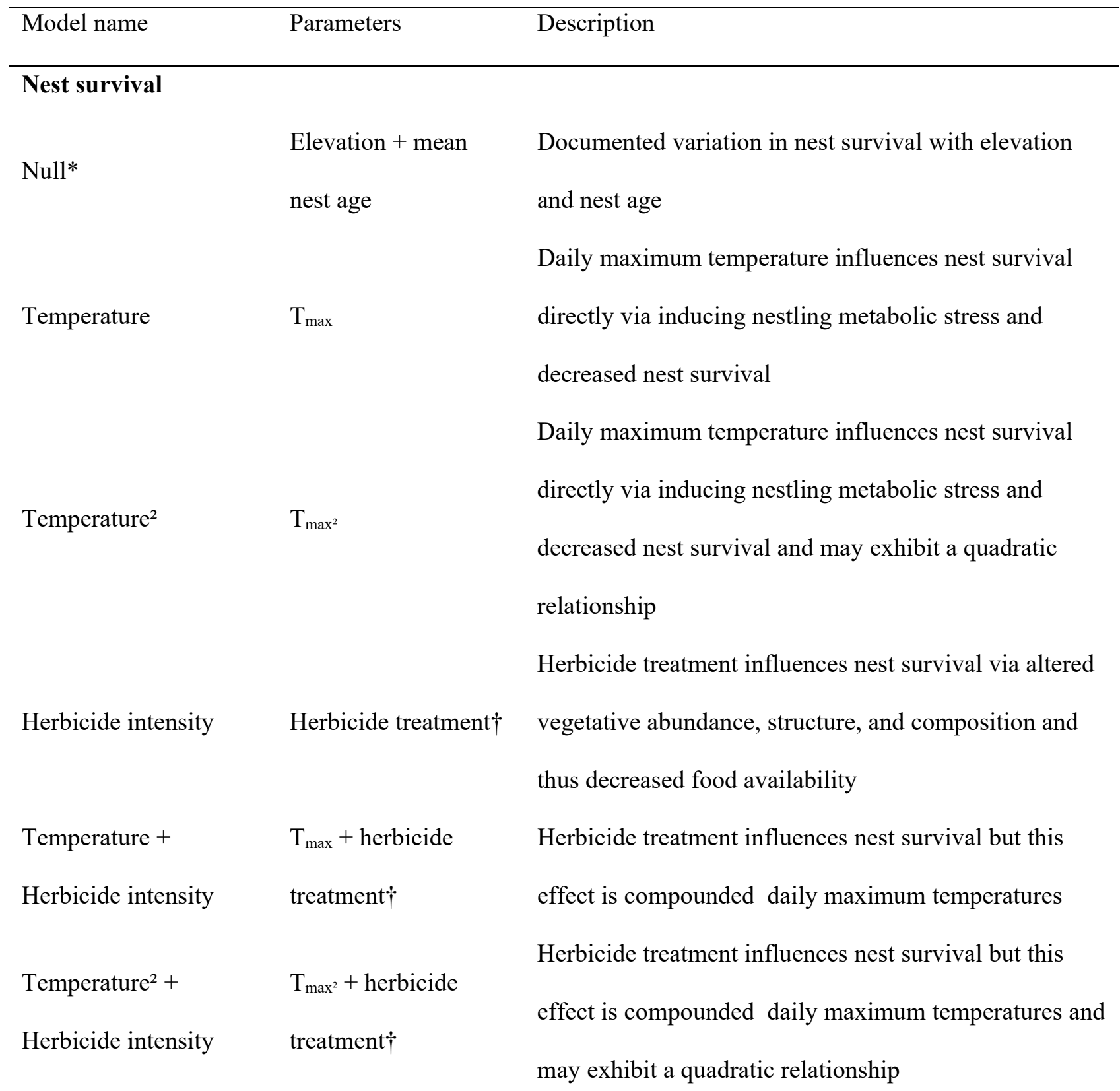




\section{Number of offspring produced}

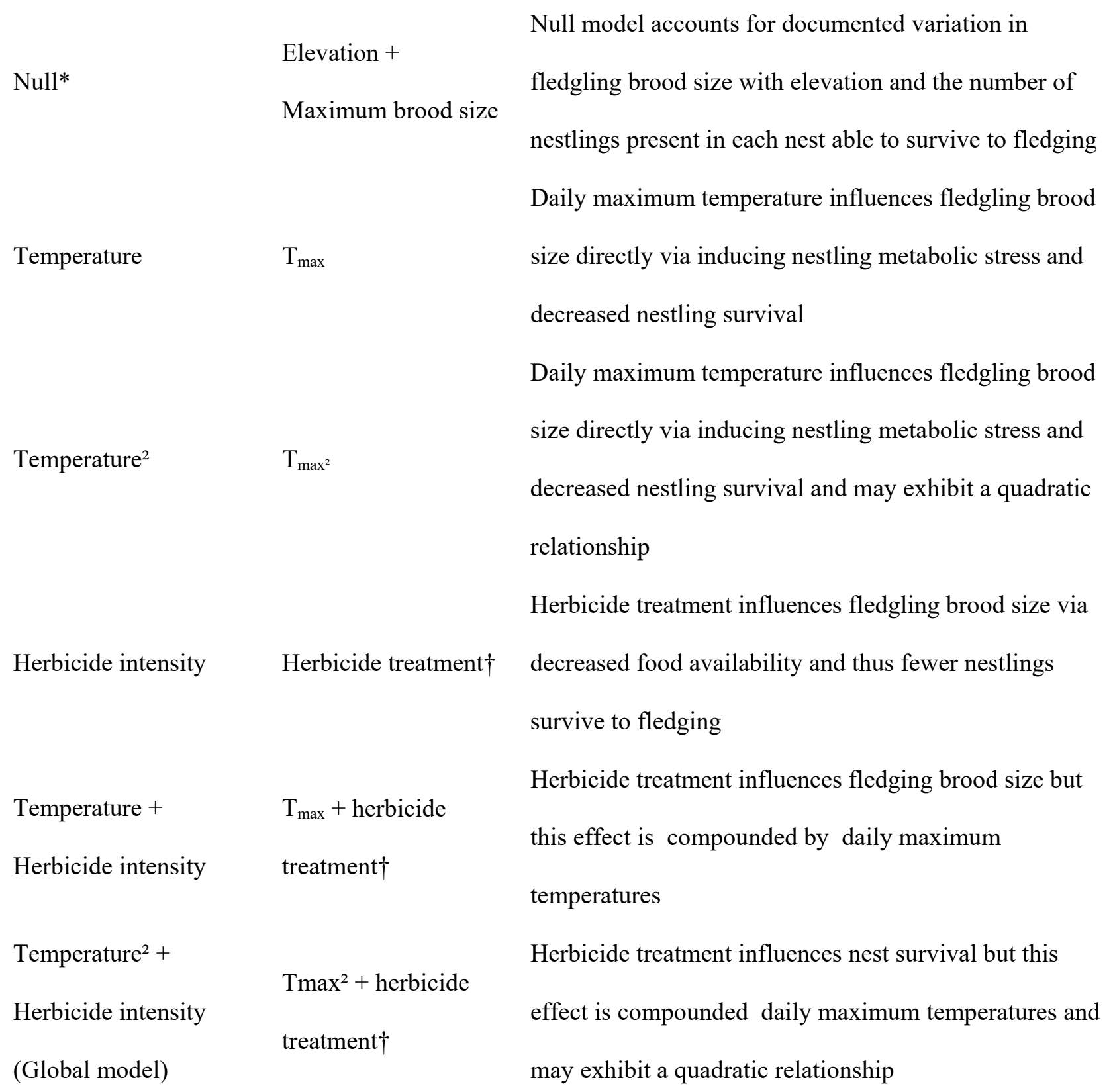




\section{Nestling body condition}

\begin{tabular}{|c|c|c|}
\hline & Elevation + Mean & Null model accounts for documented variation in \\
\hline Null* & $\begin{array}{l}\text { tarsus length }+ \text { Mean } \\
\text { nestling age }\end{array}$ & $\begin{array}{l}\text { songbird nestling mass with elevation with a factor to } \\
\text { correct for nestling size }\end{array}$ \\
\hline Temperature & $\mathrm{T}_{\max }$ & $\begin{array}{l}\text { Daily maximum temperature influences nestling mass } \\
\text { directly via inducing nestling metabolic stress and thus } \\
\text { influencing growth }\end{array}$ \\
\hline Temperature $^{2}$ & $\mathrm{~T}_{\max ^{2}}$ & $\begin{array}{l}\text { Daily maximum temperature influences nestling mass } \\
\text { directly via inducing nestling metabolic stress and thus } \\
\text { influencing growth and may exhibit a quadratic } \\
\text { relationship }\end{array}$ \\
\hline Herbicide intensity & Herbicide treatment $\dagger$ & $\begin{array}{l}\text { Herbicide treatment influences nestling mass via } \\
\text { decreased food availability and thus slower nestling } \\
\text { growth and lower mass }\end{array}$ \\
\hline Temperature + & $\mathrm{T}_{\max }+$ herbicide & Herbicide treatment influences nestling mass but this \\
\hline Herbicide intensity & treatment & effect is compounded by daily maximum temperatures \\
\hline Temperature $^{2}+$ & $\mathrm{T}_{\max }^{2}+$ herbicide & Herbicide treatment influences nest survival but this \\
\hline $\begin{array}{l}\text { Herbicide intensity } \\
\text { (Global model) }\end{array}$ & treatment $\uparrow$ & $\begin{array}{l}\text { effect is compounded daily maximum temperatures and } \\
\text { may exhibit a quadratic relationship }\end{array}$ \\
\hline
\end{tabular}

* All terms in the null model were included in the candidate set.

$\dagger$ Herbicide treatment includes four levels of intensity (i.e., control, light, moderate, intensive) 